\title{
THEORETICAL TEST
}

OLIVEIRA, Rayanne Alves De ${ }^{[1]}$, LIMA, Vinícius Mendes ${ }^{[2]}$, FRANÇA, Lucielma Cavalcante De Jesus ${ }^{[3]}$, SILVA, Lucrécia Pereira ${ }^{[4]}$

OLIVEIRA, Rayanne Alves De. Et al. Hospital pharmacy management: Logistics focus on the supply chain. Revista Científica Multidisciplinar Núcleo do Conhecimento. Year 05, Ed. 09, Vol. 03, pp. 87-98. September 2020. ISSN: 2448-0959, Access link: https://www.nucleodoconhecimento.com.br/health/hospital-pharmacy

\section{Contents}

- SUMMARY

- 1. INTRODUCTION

- 2. METHODOLOGY

- 3. LITERARY REVIEW

- 4. RESULT AND DISCUSSION

- 5. FINAL CONSIDERATIONS

- REFERENCES

\section{SUMMARY}

The hospital is a critical unit in the management process in general. This criticality becomes more pronounced when it comes to supply logistics. In the hospital unit, it is important to highlight the hospital pharmacy as an indispensable nucleus for effective and safe treatment of the patient. Objective: to identify and report the main difficulties and inefficiencies in the process of supply management in hospital pharmacies. Methodology: Literary review of articles indexed in lilacs, SPELL, Scielo, Medline and CAPES Journal Portal databases, from 2005 to 2019, on supply management in hospital pharmacies. Results: 25 articles were selected, which addressed the theme, which were critically studied, aiming to understand the supply chain process in hospital pharmacies. Conclusion: the main difficulty encountered was the effective control of inventories. As a result, at any given time, the lack of some materials and medications, thus bringing harm or damage to patients. 
Keywords: Hospital pharmacy service, hospital supply center, hospital materials administration.

\section{INTRODUCTION}

Hospital units have a variable amount of areas of knowledge necessary in the maintenance of their activities, which must be conducted appropriately so that health services are performed as effectively as possible. With this we can see why it is an area of such complexity (PRESTES, 2019).

The management of hospitals, regardless of which region he is in, requires the professional who manages it various knowledge, among them knowledge about regulation, financing, health technologies, management of physical, human and financial resources (FARIAS; ARAÚJO, 2016).

According to Sousa (2011), even in the face of the gradual evolution in the management of this type of organization, the improvement of the efficiency of the logistics of supply of hospital establishments and the effective control of costs, remains a huge challenge to be overcome in health, in view of the peculiarity of the services provided and the diversity of materials used in its realization.

Having as its central point the minimization of the cost of the operation for a given level of service, logistics is too important in the process of enabling the flow of supply of materials. It aims to achieve the expected level of customer service with the lowest final cost (PEREIRA, 2006).

According to Resolution No. 492 of the Federal Council of Pharmacy (2008), the hospital pharmacy is defined as "clinical, administrative and economic unit, directed by a pharmacist, hierarchically linked to the direction of the hospital or health service and functionally integrated with other administrative and patient care units".

The hospital pharmacy is part of the structure of the hospital and has as main goal to ensure the excellence of the care that reaches the patient, being responsible for promoting the safe and rational use of medicines and hospital supplies, prescribed by the medical professional, 
in addition to meeting the demands and needs of medications of patients hospitalized in the hospital. To do so, it needs to keep under its guard the stocks of these products (CAVALLINI; BISSON, 2010).

In this context, it is perceived that drugs have great repercussion in logistics management, and these resources are of significant importance in the process of care and care to the patient, besides being considered determining factors in the expenses of health units (NETO; SON, 1998).

Supply chain management covers some steps, including planning, organizing, pointing, and mastering all existing steps in the value optimization process of this entire chain. Thus, it understands the flows from the phase in which the inputs are acquired, their modifications and phases of distribution of the product to the reach of the product by the end user. (ACCIOLY; AYRES; SUCUPIRA, 2008).

Hospital logistics is importantly known for the reason that an error in the distribution of materials and medicines, a logisticfunction that is paramount, can lead consequently to an irremediable disaster, affecting not only the hospital, but also to patients (BARBUSCIA, 2006 apud OLIVEIRA; MUSSETTI, 2014).

This study aimed to identify and report the main difficulties and inefficiencies in the process of supply management in hospital pharmacies. It is justified, by this scenario exposed, the need for studies that such as this are necessary to investigate how logisticflow occurs in hospital pharmacies, due to the complexity of this type of inventory and the damage that inefficiency in the management process can cause in the patient.

\section{METHODOLOGY}

This is an exploratory, descriptive study, made through a bibliographic survey of articles indexed in lilacs, SPELL, Scielo databases; Medline, and CAPES Journal Portal, from 2005 to 2019 , on supply management in hospital pharmacies, the following descriptors were used for the search: hospital pharmacy service; hospital supply center; materials administration in the hospital. 
In the research, articles were selected, with this thematic approach, the selected articles underwent a critical analysis, with the objective of identifying and reporting the main difficulties and inefficiencies in the process of supply management in hospital pharmacies.

In this review, we adopted as inclusion criteria studies that contemplated the theme sought, carried out in the last 14 years, and as an exclusion criterion studies with more than 14 years of publication or that did not relate to the descriptors researched.

Within the inclusion and exclusion criteria in the selection, in the final search, a total of twenty-five (25) articles that were directly related to the theme and objectives of the study were classified for analysis, contemplating the expected criteria. Such articles were read and reread, making possible their synthesis, interpretation and critical analysis.

\section{LITERARY REVIEW}

The management of materials consists of logistics steps, among which are the choice of materials and suppliers, the acquisition, receipt, control and organization of materials in stock, storage, dispensing and assistance to the intended public (BARBIERI; MACHLINE, 2017).

This administration also applies in the health area, more precisely to the hospital pharmacy sector, to which it is entrusted with all the management of its materials and medicines, which bring with it a huge variation of items and large dimensions in the quantity. As Barbuscia (2006) reports, when he says that "Logistics is a function of the administration of materials responsible for providing materials and medicines in the time required to assist patients"

With this it is evident that logistics directs all phases through which the materials and information pass in the supply chain, from the suppliers of materials to the delivery to patients, acting in each phase of the process, to ensure that there are no failures in this process or that they are the minimum possible.

The logistics of distribution in hospitals have the duty to ensure the delivery of medicines and materials at the right time and in the requested sector. However, in these organizations often the distribution flow is not very precise and it is not always possible to accurately quantify all 
the materials that will be needed in some medical procedure. This deficiency in forecasting can lead to planning and control difficulties (PEREIRA, 2006).

The hospital pharmacy is characterized by being a sector with clinical and care skills, which has management and administration capacity, thus acting as one of the main sectors of the hospital. It has responsibility for the safe and rational supply of medicines and some medicalhospital articles, and may be linked to the clinical or administrative board of the hospital (SILVA et al., 2013).

It has several functions, ranging from the common activities of the pharmaceutical assistance cycle such as selection, programming, acquisition, storage, distribution and dispensing of medicines, as well as the management of human, financial and material resources (SILVA et al., 2013).

Inventories are essential elements to meet predictable demands, they are the ones that supply the entire production flow, thus allowing rationalizations in purchasing processes, ensuring uniformity in production processes and making it possible for institutions to practice economics. For this reason, stocks can be seen as elements intrinsically associated with the competitiveness of organizations (ACCIOLY; AYRES; SUCUPIRA, 2008).

According to Cavallini and Bisson (2010), stocks in hospital pharmacies are characterized by cycles of demands and resupplies, with frequent variations and high degrees of instabilities, critical factors due to the need to store drugs in availability in the same proportion in which they are used. These drugs in large stocks represent high costs, and in hospital institutions medicines and materials can mean up to $75 \%$ of financial expenses.

Supply chain management is an indispensable process to achieve satisfactory results between companies and customers, so that it makes it possible to control all processes, reduce higher costs and availability of the product when necessary.

It constitutes the activity of planning, implementing and controlling the flow and economic storage of raw materials, semi-finished materials and finished products, as well as the situations related to them, from the point of origin to the point of consumption, with the purpose of satisfying the interests of customers (BARBIERI; MACHLINE, 2017). 
With this, for an adequate stock dimensioning, which meets the end user well it is necessary to evaluate all flow and procedures that medicines and materials pass before they are available in hospital pharmacies, knowing all this flow, from production, availability in large companies and representatives, request, purchase order, transportation and delivery, it is possible to provide, quantify and organize the stock more assertively.

Therefore, it is essential to adequately quantify which materials and medications are most used and consumed, evaluating the relationship of this consumption with the seasonality to which they are subjected, due to the periodicity of some diseases according to the months of the year. This dimensioning should predict increases and decreases according to the use and delivery of these products, avoiding shelf expirations or lack of medications.

\section{RESULT AND DISCUSSION}

In the present study, some of the main difficulties and factors that cause interference in the management of supplies in hospital pharmacies were identified, among them are the lack of planning of medications and materials, non-active participatory management, absence of pre-established goals and lack of professional training, as well as other variants that will be discussed in the sequence.

The data of Silva et al. (2013), point out that in the pharmacies surveyed, in most of them, planning with objectives and goals was not carried out, it was also said that there was a lack of manuals of standards and procedures to direct the routines. For him, managing a hospital pharmacy carries in itself the duty to provide adequate support, in order to obtain the excellence in the offer of care and ensure the technical, scientific, clinical and administrative contribution.

According to Silva et al. (2013), no hospital among those studied included the processes and or stages of participatory management, focused on quality and results, which differs from the management model that is recommended for this hospital follow-up. The participatory management mode when adjusted to institutional philosophy has been presented as an effective solution in improving care, but unfortunately it is not the scenario found in most of the hospitals surveyed. This result shows a fragile articulation of the work of the hospital 
pharmacy with the other sectors of the hospital.

In another scenario Infante and Santos (2007), point out that the lack of regularity in the supply, sometimes the scarcity of the product and even the lack of material, are situations that often occur in public health services and bring impacts that negatively affect their performance and image before professionals and the community.

These data corroborate the studies by Andreoli and Dias (2015), which show that the negative impacts caused from the periods of shortages, caused by dysfunctions in budget compliance are not small, being significant in the institution. However, this study also evidenced the waste and misuse of medicines, supplies and hospital equipment, scarce professional improvement of the servers in the supply area and the reduced surveillance regarding logistic planning in health organizations.

Failures in logistics can cause losses in both human and financial resources, thus losing effectiveness in the proper supply of medicines. The large number of products without standardization to the detriment of standardized ones disorganizes the pharmaceutical assistance service in the hospital and produces the increase in the consumption of drugs that are not included in the list of products, this causes a possible increase in losses of standard medication at the time of expiration of the same, and interferes negatively in the planning of purchases of these drugs (BARBOSA, 2015).

In the studies by Gonçalves, Novaes and Simonetti (2006), factors similar to these are found, when they report that the rates of financial spending on medicines demonstrate that the increasing costs of the health sectors are unsustainable, both public institutions and private health organizations. Planning and controlling these expenses are means that can ensure the survival of hospital institutions.

According to Pereira (2006), chain management can offer many situations where it is possible to obtain increased productivity in establishments, as a consequence of this can significantly reduce institutional costs, and thus add greater value to the products and services provided.

From another perspective Noronha and Borges (2005), did not identify by managers or those responsible for the purchasing sector, consultation on the analysis of technical and/or 
epidemiological aspects and variations in consumption, for the definition of cuts or additions in the purchase order, did not even find concern with the quality and quantity of the products, thus revealing that they did not make these evaluations in the hospitals they researched.

The pharmaceutical professional is linked to all phases of the logistics chain of the drug, primarily he acts in the acquisition phase, and must be able to conduct technical activities such as standardization, specification and technical opinion (SFORSIN et al., 2012).

The non-use of technological resources, such as inventory control programs, hinders the management process of hospital supplies, this point was one of the inefficiencies found and one of the fragile points in the logistics process. The administration of material, human and financial resources can be done more accurately and agilely with the use of information technology (SFORSIN et al., 2012).

In summary, it is understood that in order to achieve quality in inventory management, a good organizational structure is necessary, which enables the actions of the service that require well-defined procedures, technical/scientific knowledge in the area, integrated activities and permanent search for improvements in processes and results in the logistics management of the hospital pharmacy.

\section{FINAL CONSIDERATIONS}

The hospital pharmacy service is responsible for numerous processes that have a great impact on health care. Hospital pharmacies need to perform a number of complex activities in an organized and effective way to meet the needs of the patients under their care.

In this diversity of tasks is the management of supplies, from their acquisition to their availability in local stock and at their final destination, without the proper efficiency and control of this process, it is that patients (final consumers of the products) will be underserved, and taking health risks, since the failure of this process can cause a shortage and a given patient may be without the appropriate medication and treatment.

This study found that in most of the hospitals presented there is difficulty in maintaining an 
adequate inventory control, this occurs for several reasons, from lack of specific preparation to professionals working in this area of supply management, such as difficulties to quantify the actual consumption, specificity of stocked material and even lack of financial resources in some situations.

From this, the logisticactivity of supply chain management was considered as indispensable to the proper functioning of the hospital pharmacy, in order to promote an adequate control of the stock, satisfactory supply and, therefore, more efficacy and safety to the whole hospital and to the patient.

It is recommended that further studies be done in this area and that these can contribute to the primary care provided by the hospital pharmacy service, in order to bring benefits to hospitals, users and society

\section{REFERENCES}

ACCIOLY, Felipe; AYRES Antônio de Pádua Salmeron; SUCUPIRA, Cezar. Gestão de estoques. 1 으. Ed. Rio de Janeiro: Editora FGV, 2008, pg 40-47, volume 1.

ANDREOLI, Gustavo Luís Meffe; DIAS Cleidson Nogueira. Planejamento e Gestão Logística de Medicamentos em uma Central de Abastecimento Farmacêutico Hospitalar. Revista de Administração Hospitalar e Inovação em Saúde - RAHIS v.12 n.4(2015).

BARBIERI, José Carlos.; MACHLINE, Claude. Logística hospitalar: teoria e prática. 3o Ed. São Paulo: Saraiva, 2017.

BARBOSA, Katia Simoni da Silva. Gerenciamento de Farmácia Hospitalar: Otimização da Qualidade, Produtividade E Recursos Financeiros. Revista Saúde e Desenvolvimento vol. 7, n.4 jan - dez 2015. Disponível: https://www.uninter em:.com/revistasaude/index.php/saudeDesenvolvimento/article/view/343. Acesso em: 12 jul. 2019.

BARBUSCIA, Caloger Sauveur (2006). Gestão de suprimentos na administração hospitalar pública. In: GONÇALVES, Ernesto Lima. Gestão Hospitalar: Administrando o hospital moderno. 
(Cap. 9, pag. 196-224). São Paulo: Saraiva, 2012.

CARVALHO, José Crespo De; RAMOS, Tânia. Logística na Saúde. 3ạ Ed. Lisboa: Edições Sílabo, 2009.

CAVALLINI, Mírian Elias; BISSON, Marcelo Polacow. Farmácia hospitalar. 2ํㅡ. Barueri: Manole, 2010.

Conselho Federal de Farmácia. Resolução no 492, de 26 de novembro de 2008. Regulamenta o exercício profissional nos serviços de atendimento pré-hospitalar, na farmácia hospitalar e em outros serviços de saúde, de natureza pública ou privada. Brasília: CFF, 2008. Disponível em: https://cff-br.implanta.net.br/ PortalTransparencia/Publico/ArquivosAnexos/Download?idArquivoAnexo=774c5fd9-3efd-411e -8eed-ec4206533b1c Acesso em:13 jul. 2019.

FARIAS, Diego Carlos; ARAUJO, Fernando Oliveira de. Gestão hospitalar no Brasil: revisão da literatura visando ao aprimoramento das práticas administrativas em hospitais. Ciênc. saúde coletiva, Rio de Janeiro, v. 22, n6, p.189a1904, jun.2017. Disponível em: http://www.scielo.br/scielo.php? scriptsci _arttext\&pid=S1413-81232017002601895\&lng=en\&nrm=iso. Acesso em: 23 ago. 2019.

FERRANTI, Eliane. Gestão de estoque de medicamentos utilizando classificação $A B C$ em um hospital público. Perspectiva Econômica, vol. 13, n. 3, p. 215-229, n. especial: dez. 2017.

GONÇALVES Antônio Augusto; NOVAES, Mario Lúcio de Oliveira; SIMONETTI, Vera Maria Medina. Otimização de farmácias hospitalares: eficácia da utilização de indicadores para gestão de estoques. In: Encontro Nacional de Engenharia de Produção, 26., 2006, FortalezaCE. Anais eletrônicos... Rio de Janeiro: ABPRO, 2006. p. 2- 8. Disponível em: http://www.abepro.org.br/biblioteca/ENEGEP2006_TR450302_7149.pdf. Acessado em: 4 ago. 2019.

INFANTE, Maria; SANTOS, Maria Angélica Borges dos. A organização do abastecimento do hospital público a partir da cadeia produtiva: uma abordagem logística para a área de saúde. Ciência \& Saúde coletiva [online]. 2007, vol.12, n.4, pp. 945-954. ISSN 1413-8123. Disponível em: 
scielo.php?pid=S1413-81232007000400016\&script=sci_abstract\&tIng=pt $>$.Acesso em: 30 ago. 2019.

NETO, Gonzalo Vecina; FILHO, Wilson Reinhardt. Gestão de Recursos Materiais e de Medicamentos.1ํ Ed. São Paulo: Faculdade de Saúde Pública da Universidade de São Paulo, 1998. V 12 (Série Saúde \& Cidadania). Disponível em: $<$ http://colecoes.sibi.usp.br/fsp/items/show/2372\#? c=0\&m=0\&s=0\&cv=0>. Acesso em 3 ago. 2019.

NORONHA, André Gustavo Gadelha Mavignier de; BORGES, Djalma Freire. Qualidade da gestão de medicamentos em hospitais públicos. RAP, v. 39, n. 4, 895-912, jul./ago. 2005.

NOVAES, Marcio Lucio de Oliveira; SIMONETTI, Vera Maria Medina; AFONSO, Marina Weil. Gestão de suprimentos da farmácia hospitalar com a implantação de métodos gerenciais de insumos usados em manufatura. Revista eletrônica Produção \& Engenharia. V.2 n. 1p.57-68, jan/jul. 2009.

Disponível

em: https://periodicos.ufjf.br/index.php/producaoeengenharia/article/view/28945. Acesso em: Acesso em 3 ago. 2019.

OLIVEIRA, Thomás Silva; MUSETTI, Marcel Andreoli. Revisão compreensiva de logística hospitalar: conceitos e atividades. Revista de Gestão em Sistemas de Saúde - RGSS Vol. 3, N. 1. janeiro/junho. 2014.

PEREIRA, Moacir. Um modelo de gestão de abastecimento de medicamentos em farmácia hospitalar. 2006.Tese (Doutorado em Engenharia de Produção) -Faculdade de Engenharia Arquitetura e Urbanismo - UNIMEP, Santa Bárbara D'Oeste, 2006).

PLATT, Allan Augusto. Logística e cadeia de suprimentos. 3ํe ed. - Florianópolis: Departamento de Ciências da Administração/UFSC, 2015. Disponível em: http://arquivos.eadadm.ufsc.br/ EaDADM/UAB320132/ Modulo_6/Logistica/_ material_didatico/logistica_e_cadeia_de_suprimentos-3ed-online.pdf. Acesso em: 12 jul. 2019.

PRESTES, Andréa. Manual do gestor hospitalar. Organizadores: Andréa Prestes, José Antônio Ferreira Cirino, Rosana Oliveira e Viviã de Sousa.1ํㅡ. Ed. - Brasília: Federação Brasileira de Hospitais, 2019. 
REIS Adriano Max Moreira; PERINI Edson. Desabastecimento de medicamentos: determinantes, consequências e gerenciamento. Ciências e Saúde Coletiva. 2008, vol. 13, p. $603-610$.

SILVA, Mario Jorge Sobreiro da; MAGARINOS-TORRES, Rachel; OLIVEIRA, Maria Auxiliadora; OSORIO-de-CASTRO, Cláudia Garcia Serpa. Avaliação dos serviços de farmácia dos hospitais estaduais do Rio de Janeiro, Brasil. Ciência \& Saúde Coletiva, n18(12): p. 3605 - 3620, 2013.

SILVA, Valdete Lourenço. Defict no Processo de Logística Hospitalar Desafio para uma Gestão Eficiente no Contexto da Saúde Pública Brasileira. Revista Científica Multidisciplinar Núcleo do Conhecimento. Ano 03, Ed. 08, Vol. 16, pp. 232-244, agosto de 2018. ISSN:2448-0959. Disponível em: https://www.nucleodoconhecimento.com.br/saude/logistica. Acesso em: 12 jul 2019.

SOUSA, Andréa Modesto. Logística Hospitalar: a eficiência do processo de suprimento de medicamentos na rede pública hospitalar do Distrito Federal. 2011. p. 39. Monografia apresentada a Universidade de Brasília-UNB, para obtenção do grau de bacharel em Administração.

SFORSIN, Andréa Cassia Pereira et al. Gestão de compras em farmácia hospitalar. Revista Farmácia Hospitalar, n. 16, mar/abr/mai. 2012. Disponível em: https://www.cff.org.br/sistemas/geral/revista/pdf/137/encarte_farmAcia_hospitalar_85.pdfAce sso em: 9 jul. 2019.

${ }^{[1]}$ Post-graduate student in hospital infection control by FUTURA. Specialist in Mental Health at INESPO, Bachelor of Nursing from the Federal University of Maranhão - UFMA.

${ }^{[2]}$ Graduated in Logistics Technology from the Federal University of Tocantins-UFT.

${ }^{[3]}$ Specialist in Obstetrics and Neonatology at CEUMA. Bachelor's degree in nursing from the San Francisco School of Education.

${ }^{[4]}$ Specialist in Occupational Nursing, ICU and Urgency and Emergency by INESPO. Bachelor of Nursing from the Federal University of Maranhão -UFMA. 
Submitted: August, 2020.

Approved: September, 2020. 